\title{
Legislation jeopardizes safe injection sites
}

$\mathrm{T}$ he House of Commons has passed a bill that, if approved in the Senate, will create major obstacles to establishing new supervised injection sites and may jeopardize the continued operation of an existing clinic.

Bill C-2, An Act to Amend the Controlled Drugs and Substances Act (also called the Respect for Communities Act), passed by a vote of 143-108 on Mar. 23, as Treasury Board President Tony Clement announced on Twitter.

Conservative House Leader Peter Van Loan also tweeted his support for the bill in a statement that articulates the federal government's position: "Neighbourhoods will finally have a say when drug injection sites try to set up shop."

Those opposed to the bill put it another way: "My neighbours will die," said Adrienne Smith, drug-policy lawyer with the Pivot Legal Society. Smith has testified before the House of Commons' Standing Committee on Public Safety and National Security that safe injection sites prevent drug overdose deaths.

The bill states that organizations applying to operate a safe injection site must garner support at 26 levels, ranging from a provincial health ministry to public consultation. Failure to get support at even one level scuttles the whole application. Advocates say this will make it nearly impossible to get a new site approved.

Because possessing and injecting drugs remain criminal activities, harmreduction sites, such as the Insite supervised injection site in Vancouver, must apply to the federal health minister for an exemption to the Controlled Drugs and Substances Act. The government will only grant those exemptions "under exceptional circumstances," the bill states. Insite's exemption is to expire at the end of March.

"The way the legislation is structured right now, it effectively gives veto power to multiple players at multiple levels to try to block the application," says Richard Elliott, executive director of the Canadian HIV/AIDS Legal Network. "There's no question that Insite will have

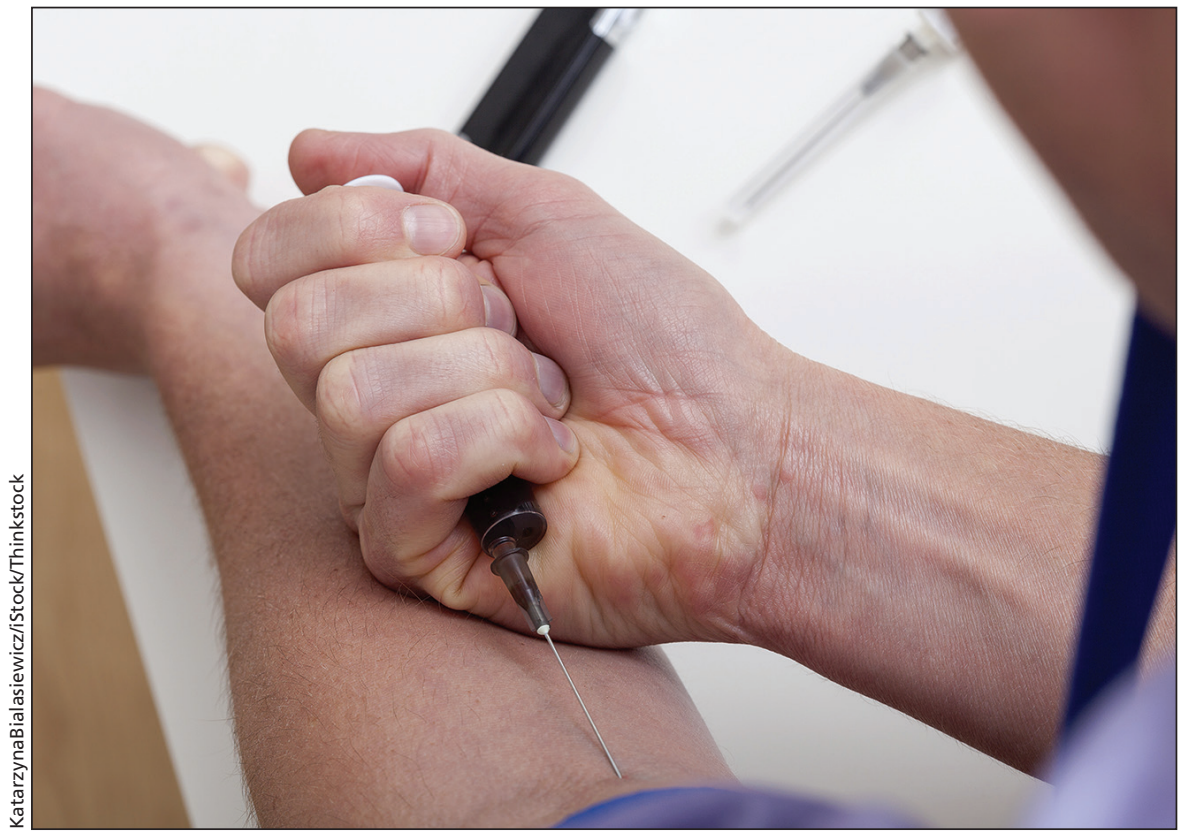

Parliament's new bill appears to contradict a 2011 Supreme Court of Canada decision allowing supervised injection sites.

to satisfy the requirements of the [new] legislation to continue."

The Canadian Nurses Association, one of the first groups to react to the vote, decried the government's position, saying it will "overshadow evidence that demonstrates positive outcomes for communities with harm reduction programs."

"In Vancouver's Downtown Eastside, where the Insite safe injection site is located, business owners, service providers and residents in the neighbourhood agree that the clinic has had a positive impact on the health of the people who use it and on the health of the community," the association said in a statement.

The legislation's language appears to contravene the direction of a 2011 decision from the Supreme Court of Canada that upheld Insite's exemption. The court also instructed the federal government to generally grant exemptions, if there is little or no negative impact on public safety, and if the sites reduce death and disease.

At that time, major medical and public health organizations across the coun- try, including the Canadian Medical Association, supported Insite's exemption request and the evidence that its services reduce overdose deaths and the transmission of infection, says Dr. Thomas Kerr, co-director of the Addiction and Urban Health Research Initiative at the British Columbia Centre for Excellence in HIV/AIDS. Kerr and his colleagues provided the body of evidence supporting Insite's harm reduction work. Kerr also coauthored an Oct. 15, 2013 CMAJ commentary supporting supervised injection sites.

"This is another example from the federal government of giving precedence to ideology over evidence," Kerr told $C M A J$ in an interview. "It shows again how this government is discriminating against a very vulnerable segment of our population - people who inject drugs. We wouldn't do the same thing to a program that was serving disabled children or adults with other conditions."

Health Minister Rona Ambrose insisted, during remarks in the House of Commons, that the government is abiding by the Supreme Court ruling. 
"We will continue to support treatment and recovery programs that get addicts off drugs and help them recover drug-free lives," she said. She also chastised Liberal Leader Justin Trudeau's "shameful" support for "opening heroin injection sites across Canada."

"As Health Minister, I'll follow the Supreme Court ruling and make sure that communities have a voice," Ambrose said.
The bill now heads to the Senate, where it is expected to pass and receive Royal Assent before the anticipated federal election in October.

An intense advocacy effort by 121 civil society groups and the testimony of medical experts who say safe injection sites save lives and health care dollars failed to affect the outcome of the vote. Elliott hopes the Senate will live up to its name as the chamber of "sober second thought," he told CMAJ.

Many nurses took to Twitter to express their outrage about the vote, including Shannon Riley, a nurse at the Insite clinic who wrote: "We NEED supervised injection rooms! We saved someone from an overdose today." Laura Eggertson, Ottawa, Ont.

CMAJ 2015. DOI:10.1503/cmaj.109-5030 